\title{
溶接シミュレーションソフトの開発
}

\author{
Development of simulation software for MAG arc welding \\ 黄地尚義(大阪大学)
}

\author{
Takayoshi OHJI, Osaka University, Dpt. of Adaptive Machine Systems
}

\begin{abstract}
One of the important problems in the welding engineering is to construct a mathematical model for the computer simulation of the welding process in a manufacturing environment.

In the first part of the present work, a simple mathematical model for MAG (Metal Active Gas) arc welding, based on the heat flow equation and the molten pool balance equation, has been introduced to make clear the influence of various process parameters on the weld bead formation. And it is made clear that the model is capable of predicting the MAG arc welding process, including multi-pass welding.

In the second part, a simulation'software for the virtual welding system, based on the MAG welding process model, has been proposed. In the software, the process model has been linked to a metallurgical and mechanical model, developed in the project, to simulate the MAG arc welding comprehensively. According to the software, the weld-geometry and the weld-deformation including the temperature history in the work-piece for the inputted process parameters are easily estimated, and the dynamic behavior of molten pool and weld-deformation are reproduced visually by using an animation technique.
\end{abstract}

Key words: MAG arc welding, simulation, software, weld geometry, deformation, virtual welding.

1 はじめに

技術者は、与えられた溶接構造物に対し、適切な溶接 施工法、施工条件を選択・決定しなければならない。こ の決定には高度な技術的判断が要求され、技術者には、 各施工法に関する広籁、かつ梁い知識が必要亡される。 溶接現象の解析手法としてシミュレーションが有用であ ることは云うまでもないが、施工法の選択、施工条件の 設定・最適化など、技術者の意思決定を支援するツール としてもシミュレーションは重要である。

このような観点から、ここでは、アーク溶接プロセス のシミュレーション技術を確立し、その成果をもとに、 溶接技術者の意思決定を支援できるシステムを提案する ことを目標としている。

2 溶接プロセスのシミュレーションモデル

本研究で提案・検討した溶接プロセスモデルを Fig.1 に示す。ここでは、モデルの複雑さを回避し、演算時間 を短縮するため、溶接部の熱輸送は熱伝導により支配さ れると仮定している。また、溶接プール表面は、重力、 表面張力、アーク圧力の平衡により決定されるものと仮 定している。

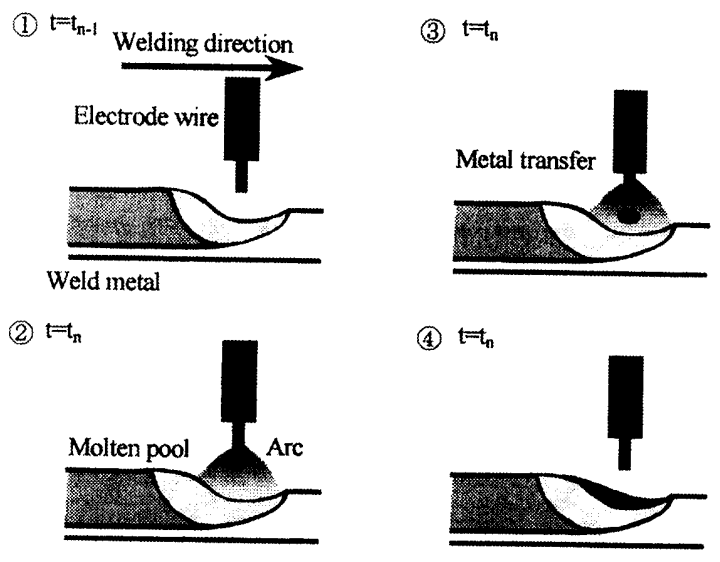

Fig.1 Model of MAG arc welding process
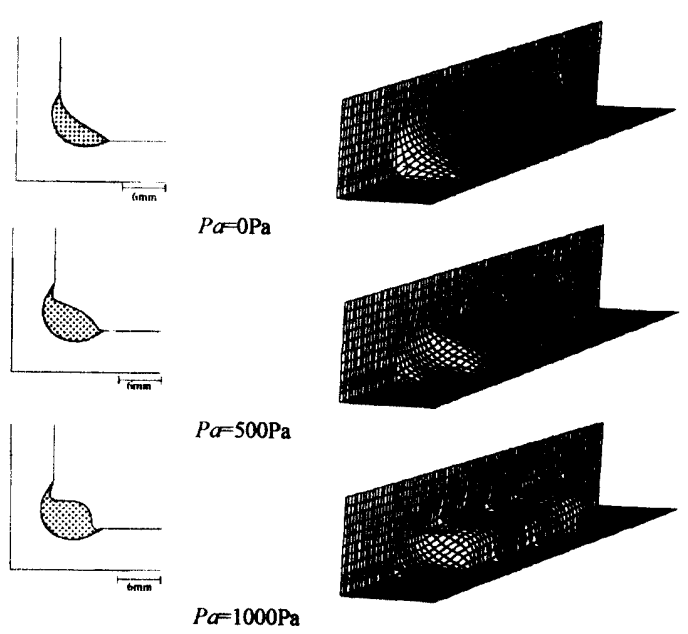

Fig.2 Effect of arc pressure on horizontal fillet weld

$$
(I=230 \mathrm{~A}, V=25 \mathrm{~V}, v=40 \mathrm{~cm} / \mathrm{min})
$$

Fig.2 は、MA G 溶接プロセスモデルによる計算例で、 水平隅肉溶接に及ぼすアーク圧力 $P a$ の影警を示してい る。右図が溶接ビードの形態で、左図がほぼビード中央 部におけるビード横断面の形状である。図から、アーク 圧力が強くなるにつれてビードの形成が不規則となり、 アンダーカットが形成されることがわかる。また、図は、 アーク圧力の增加につれてプール表面が圧し下げられ、 アークによる熱が、この表面上に投与される結果、溶込 みが深くなることを示している。

Fig.3 は、多パス溶接に関する計算例で、下向の隅肉 溶接を対象としている。各パスとも同じ溶接パラメータ を用いているにもかかわらず、パス数の增加につれて、 母材（ワーク）に熱が蓄積される結果、母材の溶込みが 增大していくことがわかる。なお、多パス溶接において は、溶接部の金属は複雑な熱影響を受けることになる。 


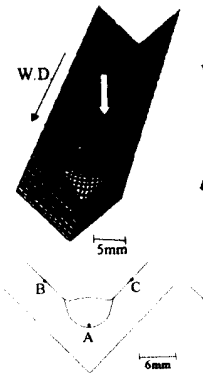

(a) First pass

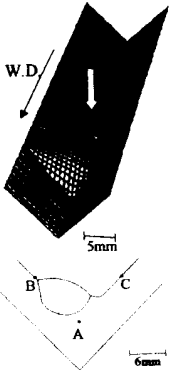

(b) Second pass

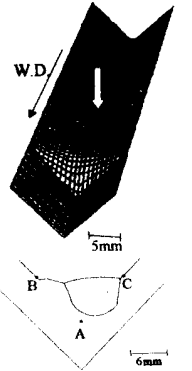

(c) Third pass
Fig.3 Multi-pass fillet welding

$(I=230 \mathrm{~A}, V=25 \mathrm{~V}, v=40 \mathrm{~cm} / \mathrm{min}, P a=800 \mathrm{~Pa})$

以上では、プロセスモデルによる計算例を簡単に紹介 した。このモデルは、実施工で用いられるウィービング 付きの溶接や各種姿勢溶接へも容易に適用できる。

なお、プロセスモデルによる計算結果の信頼性に関し ては、アーク溶接ロボットを用いた検証実験を実施し、

ほぼ満足すべき結果を得ている。

\section{3 モデル統合化による溶接設計支援システムの試作}

\section{1 基本的考え方}

上述のように、本研究で提案した溶接プロセスモデル は、生産現場における溶接プロセスをシミュレートする ツールとして十分有効であると判断される。ここでは、 この溶接プロセスモデルを、開発中の溶接金属組織・溶 接変形モデルとリンクさせ、溶接プロセスから金属組 織・変形までをトータルに予測・推定できるシステムを 試作・検討している。Fig.4に試作中システムのイメージ、 すなわち、Virtual Welding System を示す。

図のように、このシステムの特徵は、溶接プロセスの シミュレーション結果をベースに、溶接に伴う材料組織 の変化とその機械的特性、さらには溶接変形や残留忘力 分布の予測などをリンクさせ、これらを包括して、シミ ュレーションの対象としていることである。すなわち、 プロヤスモデルは、材料とその物性值、継手形式と開先 形状、溶接電流や速度等の溶接パラメータを入力データ としてシミュレーションを実行し、その結果、たとえば 温度場と熱履歴、溶接ビードの形状・寸法を出力する。

さらに、溶接変形モデルでは、例えばプロセスモデル の出力結果を入力データとし、溶接変形と残留応力状態 を予測・推定する。もちろん、その結果を、組織モデル とプロセスモデルにフィードバックすれば、溶接変形を

リアルタイムでプロセスシミュレーションに反映させる こともできる。なお、システムを構成している各モデル をモジュール化しておけば、モデル単体で利用すること もできるし、モジュールを取替えることにより、多様な システムが桠築できることになる。

\section{2 出力例}

Fig.5は、開発中の統合化したシミュレーションソフト による出力例である。図は、T一継手のMA G 溶接に関 するもので、実線で示した部分が、溶接前の部材形状を、 網がけした部分が、溶接後の部材形状を示している。 当然のことながら、溶接の結果としてワークが、複雑 に変形する。この例では、角変形に加えて䋛曲がりが、 強く現れている。

溶接とは、本来、プロセス・組織・変形の 3 要素が、 密接かつ複雑に絡み合った現象である。すなわち、これ らの 3 要素を統合化して、初めて、真の溶接シミュレー ションが可能になる。

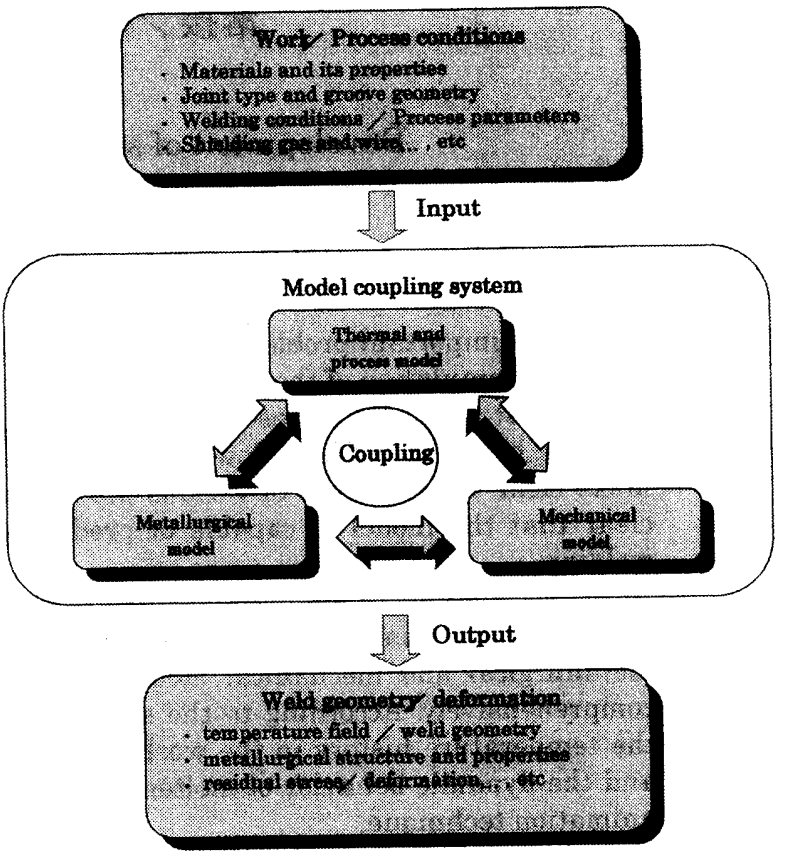

Fig. 4 Virtual welding system

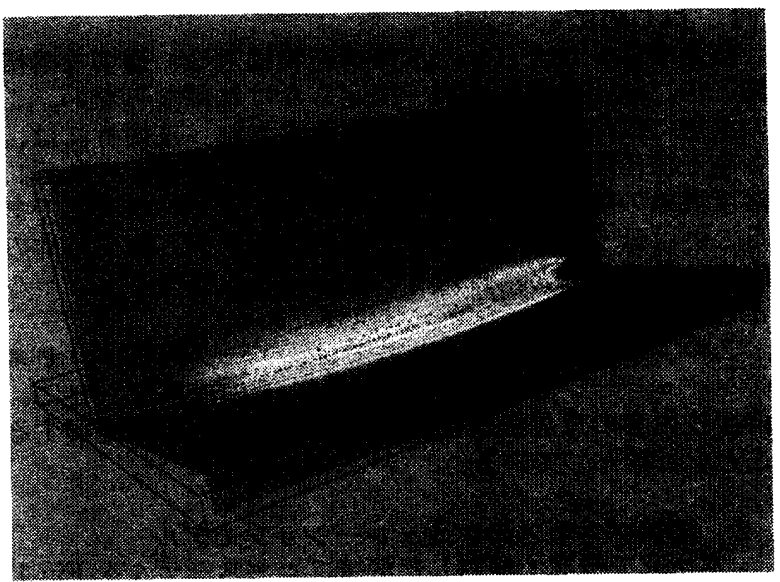

Fig.5 Output example by virtual welding system

under development

\section{4 結び}

ここでは、生産現場で利用可能な溶接プロセスモデル の開発を目的として検討した。また、開発した溶接プロ セスモデルを溶接金属組織・溶接変形モデルと統合化し、 複雑な溶接現象を包括的に予測・推定する溶接シミュレ ーションシステムを提案し、そのプロトタイプを試作・ 検討した。

統合化システムの信頼性は、プロセスモデルの信頼性 に強く依存する。このような観点から、プロセスモデル の適用範用の拡大と信頼性を高めることが、今後の重要 な課題である。

\section{5 謝辞}

本研究は経済産業省重要地域技術開発制度の一環と して、NEDOからJSUPを通じて委託された「溶接 技術の高度化による高効率・高信頼性溶接技術の開発」 の成果である。 